\title{
ATR vowel harmony in Ateso
}

\author{
David Barasa \\ Linguistics Section, University of Cape Town, South Africa \\ E-mail: barasa.david1@yahoo.com
}

\begin{abstract}
Vowels in Ateso, an Eastern Nilotic language, are subject to Advanced Tongue Root (ATR) harmony. Accordingly, the vowels are divided into two harmony sets which differ in terms of tongue root position. The two sets of tongue root position are the Advanced Tongue Root [+ATR] set and the Retracted Tongue Root [-ATR] set. Comparably, Bari and Lutuko, related Eastern Nilotic languages, have a ten-vowel system consisting of five closed and five open vowels, with clearly discernible laws of ATR vowel harmony (Tucker \& Bryan 1966: 444). A similar system applies to Ateso which has the following nine phonemic vowels: /i i e $\varepsilon$ u $v$ o $\rho \mathrm{a} /$ and the phonetic vowel [ä]. The presence of the [ä] variant is conditioned by neighbouring [+ATR] vowels or glides, and hence does not have phonemic status; instead, it is treated as an allophone of $/ \mathrm{a} /$. In this paper, I follow the general discussion of vowel harmony in African languages (e.g. by Casali $(2003,2008)$ ), albeit in Ateso. Firstly, I introduce the Ateso vowel articulatory parameters and the phonetic realisation of /a/. Secondly, I show that in Ateso /a/ behaves like an underlying [-ATR] vowel and that, generally, though the ATR affects tongue height and thereby accounts for the relative tongue height, ATR is not a category of tongue height but rather of the position of the tongue root. Lastly, I demonstrate that Ateso ATR vowel harmony has two dimensions. One is the condition that vowels ideally belong to a [-ATR] or [+ATR] set within a word and the second is that there is a dynamic dimension where ATR qualities may change as a result of affixation.
\end{abstract}

Keywords: ATR, assimilation, vowel harmony, Ateso, Nilotic

\section{Introduction}

The differences in Ateso ${ }^{1}$ vowel features are based on the articulatory parameters that relate to the positions of the tongue and the root of the tongue. These distinctive features, as introduced in the feature matrix below in Table 1, define the different vowel sounds and their interaction.

\footnotetext{
${ }^{1}$ Ateso is spoken by the Iteso who live in the Teso sub-region of Uganda and parts of Western Kenya (Barasa 2015). The language belongs to the Teso-Turkana sub-group of the Eastern Nilotic branch. The Eastern Nilotic branch also consist of Bari and Lutuko.
} 
Table 1: Ateso's vowel phoneme features

\begin{tabular}{llllllllll}
\hline & $\mathrm{i}$ & $\mathrm{e}$ & $\mathrm{o}$ & $\mathrm{u}$ & $\mathrm{a}$ & $\mathrm{I}$ & $\varepsilon$ & o & $\mathrm{U}$ \\
\hline ATR & + & + & + & + & - & - & - & - & - \\
High & + & - & - & + & - & + & - & - & + \\
Mid & - & + & + & - & - & - & + & + & - \\
Back & - & - & + & + & + & - & - & + & + \\
Low & - & - & - & - & + & - & - & - & - \\
\hline
\end{tabular}

Vowels are classified as either high, mid or low, either [+ATR] or [-ATR], and either back or front. Voicing and syllabicity are non-distinctive in the vowels since all vowels in the language are [+voice] and [+syllabic], except in word-final position, where they can also be devoiced. In other words, there are voiceless counterparts for each of the voiced vowels but the former has the same features as their corresponding voiced forms except for the feature voiceless.

The vowels of Ateso for any word will be drawn from any one of the two harmonic sets according to the presence or absence of the feature ATR. All other retracted positions have advanced counterparts, commonly referred to as "harmonic counterparts".

Generally, consonants for most languages in the Nilo-Saharan family do not participate in the ATR harmony system and consequently do not trigger changes in the ATR quality of the vowels. However, Casali (2008) cites sources indicating that there are some languages in the Nilo-Saharan family such as Didinga, Kalenjin, Karamojong', Turkana, etc., where semivowels [j] and/or [w] can interact with the ATR value of vowels (e.g. by causing adjacent values to become $[+$ ATR $]$ ).

\section{The tenth vowel}

Fundamentally, there is an important structural difference between the Bari and Teso language groups in that in the former [ä] is in structural opposition with /a/, whereas its distribution in Ateso is predictable. Unlike the other members of the Teso-Turkana group, which lost the tenth vowel */ä/ structurally as well as phonetically, Ateso retained this feature phonetically; in other words, -ATR [a] never occurs after a glide in Ateso. This assimilation of the low [-ATR] vowel /a/ after a glide is also found in the neighbourhood of low vowels, if these occur, as in [äkkwầnä̀] "swim". CV(C) or -VC root structures (i.e. root structures without a glide in the syllable onset) with a [-ATR] vowel [ä] do not occur in Ateso.

Dimmendaal (2012: 157), in his comparative study, observes that cognates of the vowel [ä] in the two branches of the Teso-Lotuko-Maa group, i.e. either in Lotuko-Maa or Teso-Turkana, confirm the claim that $* / \ddot{a} /$ shifted to and merged with /a/ in lexical roots. Thus, [ä] goes back to the original phoneme $* / \ddot{a} /$, but is now entirely predictable from a synchronic point of view in Ateso. Compare the Ateso examples with their cognates in Bari and Lotuko, as adapted from Dimmendaal (2002: 158).

Bar
bwät

\section{Lotuko}

-bwät "skin" (V)

\author{
Ateso \\ äki-bwätä (V) \\ INF-skin \\ "to skin"
}


$\begin{aligned} \text { lwäk "rescue" -lwäk "rescue" äki-lwäk } & \text { INF-rescue } \\ & \text { "to rescue" }\end{aligned}$

(See Dimmendaal 2002, for further details)

The second position in which the low [+ATR] vowel [ä] occurs, again as an allophonic variant of [-ATR], is either before or after [+ATR] vowels in the same root or in adjacent affixes as in, [ékä̀rù] "year". Consequently, at the phonetic level one does not find words in Ateso with [a] preceded or followed by [+ATR] vowels. The following examples illustrate the phonetic realisation of $/ \mathrm{a} /$ and the corresponding structural (phonemic) representation of this vowel in different positions within the word.
a. [è-tjä̀n] /è-tjày/
M-beast
"beast"
b. [äkì-bwà]] /ákì-bwà/
INF-hide
"to hide"
c. [äkì-kwầnầ]] /ákì-kwànà/
INF-swim
"to swim"
d. [ä́kì-tjầk] /ákì-tjàk/
INF-divide
"to divide"
INF-stretch-IT
"to stretch oneself"
e. [ä́kì-bòjầàr] /ákì-bòjà-àr/
f. [é-kä̀rù] /é-kàrù/
M-year
"year"
g. [ä̀-bìlà] /à-bìlà/
F-shrine
"shrine"

The two conditioning factors, the presence of a glide and the presence of [+ATR] vowels, are sufficient to predict its phonetic realisation in Ateso (though not in a language like Bari). Examples in (2) show that the tenth vowel [ä] is not restricted to any particular position in a word. It may occur word-initially, word-medially or word-finally. This vowel may also appear in a sequence, as in a verb phrase [ầbòjầầ] "to stretch oneself". Moreover, the vowel occurs in different word categories. The underlying [-ATR] status of root vowels phonetically realized as [ä] becomes obvious when looking at suffixes which themselves are underlyingly [-ATR] in terms of vowel harmony. 
Consequently, there are ten vowels phonetically, but nine phonemically - meaning that throughout the rest of this paper it suffices to use one symbol ("a"), unless there is a representation of phonetic realisations (in which case "ä" is used).

\section{Transparent vs. Opaque}

According to Gafos \& Dye (2011), "the issue of how deterministic phonetic forces may be of phonological behaviour", when we also consider that what appears to be the same vowel, may be transparent in some languages but opaque in others. For instance, Dimmendaal (1983: 17) includes [a] in the [-ATR] set in the analysis of Turkana - a language in the Eastern Nilotic branch. In Toposa, another Eastern Nilotic language, the [a] is also included in the [-ATR] set but its function is that it is opaque.

Ateso has a nine-vowel system and identifies [a] as having [-ATR] qualities which is contrasted with the corresponding [ä] that is [+ATR]. In example (3a), (3b) and (3c)/a/ occurs with [-ATR] vowels while in (3d) and (3e) it occurs with [+ATR] vowels because the latter occur after a glide and with [+ATR] vowels.

(3) Illustration of the distribution of [a] and [ä] in Ateso words
a. [àdźkâ]
"disease"
b. [غ̇kíkàpút]
"basket"
c. [àdókét]
"a ladder"
d. [ä̀kísísjầ]
"to teach"
e. [ä́ísísjâ̈]
"to teach"

As stated earlier, in a structural-phonological presentation, the tenth vowel [ä] is predictable. The /a/ occurs in the same word with either the [+ATR] or [-ATR] as predictable variants.

The examples in (3) show the behaviour of /a/ in Ateso in terms of vowel harmony. They show that it behaves like an underlying [-ATR] vowel in suffixes, like other [-ATR] vowels in the language do. In Ateso suffixes, /a/ alternates with /o/ and / $/$, the alternation between the latter two depending on whether mid-vowel assimilation applies or not. The vowel /a/ does not alternate in prefixes and roots; in these contexts, it behaves like a neutral vowel. However, it behaves like a transparent vowel in that it allows [+ATR] vowels following /a/ to spread their (dominant) feature to vowels preceding /a/. The vowel /a/ itself is realized as [ä] in such cases, which from a phonological point of view is entirely predictable. These various processes are illustrated in the following section.

\section{Vowel assimilation strategies}

In Ateso an underlying [+ATR] vowel will always cause any [-ATR] vowel to assimilate to [+ATR]. However, at a more complex level, vowel assimilation strategies differ as will be illustrated in the sub-sections below. Ateso's vowel assimilation strategies are constrained by three vowel harmony rules. The three types of vowel harmony are: root-controlled, featurecontrolled or mid-vowel assimilation. 


\subsection{Root-control}

Consider examples (4) and (5) below. These examples show that gender prefixes and inflectional person markers prefixed on the nouns and verbs in (4) and (5), respectively, are susceptible to assimilation, where their ATR quality is caused to be the same as that of the root vowels. For instance, the masculine gender prefix $\varepsilon$-in (4b) is $e$-when attached to the root tóri which has [+ATR] vowels, the [+ATR] diminutive gender prefix $i$ - does not change its quality when attached to the root kókù in $(4 \mathrm{~g})$ which also has [+ATR] nucleus. Similarly, the 3SG in (5c) is $\varepsilon$ - following the root minà that has [-ATR] vowels. Causative markers also occur as [+ATR] as with to- in (6a) or with a [-ATR] vowel quality as illustrated by example (6b). Hence, causative prefixes are also recessive and they simply alternate their ATR values to be the same as that of the root vowels that they are attached to.

(4)
a. è-tórì
M-eagle
"eagle"
b. $\grave{\varepsilon}-\mathrm{môy}$
M-bull
"bull"
c. è-kíljôk-ìt
M-man/husband-SG
"man/husband"

d. à-kóìt

F-bone

"bone"
e. à-kغ̀jứ
F-leg
"leg"
f. Ì-ràìt-òn
F-crops-PL
"crops"
g. í-kókù
D-child
"child"
h. Í-ljàtók
D-grandchild
"grandchild"

(5) a. é-pègà

3SG-argue

"(s)he argues" 
b. í-líp

3SG-pray

"(s)he prays"

c. '́-mìnà

3SG-love

"(s)he loves"

(6)
a. é-tò-pòròrì-tè
3-CAUS-jump-PL
"they caused to jump"
b. દ́-tว̀-mòn
3SG-CAUS-cry
"(s)he caused to cry"

At a more abstract or morpho-phonological level, gender and person prefix vowels are [-ATR] (cf. Barasa 2017). They become [+ATR] adhering to the ATR quality of the vowels of the root. On the other hand, the harmony that applies to suffixes is either feature-controlled or is constrained by mid-vowel assimilation, both of which are discussed in the sub-sections below.

\subsection{Feature-control}

There are two types of suffixes in the language: (1) suffixes which do not trigger harmony changes, and (2) suffixes with underlying [+ATR] which do cause harmony changes to the stems that they are attached to. Dative suffixes are underlyingly [-ATR]. Thus, beneficiary roles are expressed by dative markers -akın or -skın. The two variants of the dative morpheme are phonologically conditioned by the ATR quality of the verb root vowels. The marker -skIn occurs with verbs that have [+ATR] vowels while -akın is used with verbs that have [-ATR] nucleus. Whereas the Ateso dative choice between -skın or -akın depends on the vowel qualities of the root, the nucleus of -skın which is underlyingly [-ATR] changes its values to [+ATR] to conform to those of the verb stem nucleus that they are affixed to. Below, in example (7), the verb stems without the dative or derivational morphemes are on the left while the derived forms are on the right.
a. é-búk
é-búk-ókín
3SG-pour
3SG-pour-DAT
"(s)he pours"
"(s)he pours for"
b. é-dùk
é-dùk-òkìn
3SG-build
3SG-build-DAT
"(s)he built"
"(s)he built for"
c. $\dot{\varepsilon}$-màl
ع́-màl-àkìn
3SG-greet
3SG-greet-DAT
"(s)he greets"
"(s)he greeted for" 

d. ákì-lèm
ákì-lèm-àkìn
INF-remove
INF-kick-DAT
"to remove"
"to remove for"

The verbs $\dot{e}$-búk and $\dot{e}$-dùk, in (7a) and (7b), respectively, with [+ATR] root take the dative form -okın while those with [-ATR] root vowels in (7c) and (7d) take -akın. These affixes do not affect the ATR quality of the verb root that they are attached to.

On the other hand, strong suffixes trigger ATR shift from [-ATR] to [+ATR] in roots since they themselves are always [+ATR]. As Casali (2008) discusses, this is the "normal" thing that happens in nine-vowel ATR systems: [+ATR] is dominant. The leftward-spreading is typical in other well described Eastern Nilotic languages. The suffixes do not conform to the general harmony patterns of the word root as is the case with weak vowels. Based on terminologies adapted from Casali (2008: 13), the imperfective, the passive and reciprocal voice, $-i,-o i$ and $-o$ morphemes, respectively, in Ateso are dominant affixes since they do not alternate in their ATR values, but are invariantly [+ATR], whether attached to a [+ATR] or a [-ATR] root. The three dominant suffixes trigger ATR shift on preceding vowels to become [+ATR]. In the examples below, on the left of each pair are underlying forms while those on the right are intermediate.
a. |ć-mòn-غ̀nغ̀n-è-tè $\longrightarrow$ /é-mòn-ènèn-è-tè/ 3SG-cry-HAB-IPFV-PL 3SG-cry-HAB-IPFV-PL
"(s)he used to cry (habitually)"
b. |á-jàk-ùn-òi $\mid \longrightarrow \quad$ /á-jàk-ùn-òi/
1SG-return-VEN-PASS 1SG-return-VEN-PASS
"I was being returned to the addresser"
c. |ć-mìn-àkìn-ò-sì $\mid \longrightarrow \quad$ /é-mìn-àkìn-ò-sì/ 3-love-DAT-REC-PL 3-love-DAT-REC-PL
"they love each other"

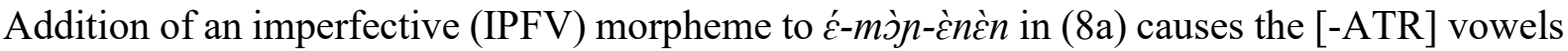
in the verb stem to become [+ATR]. This is also the case with $(8 \mathrm{~b})$ and $(8 \mathrm{c})$ where the [+ATR] values of the passive -oi and the reciprocal marker $-o$ (which are harmonising features) causes

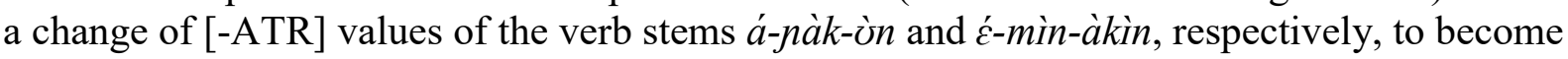
[+ATR].

Essentially, it should be noted that Ateso vowel feature harmony operates within circles. Consider example (8c) above repeated here below.
a. é-mìn-àkìn 3SG-love-DAT
"love for"

b. |ć-mìn-àkìn-ò-sì|

/é-mìn-àkìn-ò-sì/

3-greet-DAT-REC-PL

"they greeted each other" 
Firstly, vowel harmony occurs within the lexicon, as exemplified in (9a) where the derivational suffix is added to the root. Because the root contains a [-ATR] vowel $I$, the dative suffix is -akin, rather than -okin. Secondly, the REC /o/ is an underlying [+ATR] vowel morpheme, i.e. it is dominant as a [+ATR] vowel, which causes vowels to the left to become [+ATR]. The two extensions consequently have different ATR values which would not be the case if they were added at the same time.

\subsection{Mid-vowel assimilation}

As illustrated in the feature matrix above (Table 1), Ateso has four mid-vowels. Mid-vowels

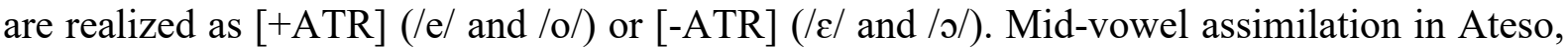
first noted by Otaala (1981), is a morpho-phonological process that applies to the aforementioned vowels. When itive markers (with mid-vowels) are suffixed to verb roots that consist of mid-vowels, a regressive assimilation applies (cf. Otaala 1981). Root vowel qualities thus change to conform to the [-ATR] qualities of the itive morpheme. The first set in each example in (10) thus appears as the corresponding set on the right when extended by the itive morphemes.
a. àkí-pét
à-pét-ór
INF-kick
INF-kick-IT
"to kick"
"kick away from the speaker"
b. àkí-pòk(ò)
INF-harvest
"to harvest"
à-pòk-òr
INF-harvest-IT
"to harvest (especially maize from the field) and bring home"
c. à-kòk̀̀
"to steal"
INF-steal
à-k’̀kò-àr
INF-steal-IT
"to steal from"

The itive marker (and its allomorphs) is basically a [-ATR] suffix underlyingly. Consequently, the roots pet and poko which are [+ATR] underlyingly are realized as [-ATR] if followed by an itive suffix $-2 r$. This process (also attested in Toposa by Schroeder \& Schroeder 1987) always applies on [+ATR] mid-vowels.

\section{Conclusion}

The ten vowels in Ateso are divided in half by discernible laws of vowel harmony, consisting of five [+ATR] and five [-ATR] vowels. The ATR value of the extensions' peaks always occurs following the values of vowels of a word root. However, some exceptions exist where harmonising affixes cause root vowels to change their ATR value to be the same as that of the affixes. The imperfective, passive and reciprocal markers have dominant [+ATR] features. These vowels cause a change in the ATR value of [-ATR] vowel root values to [+ATR]. A further challenge to the universality of features supported by theoretical claims on the ATR harmony in Nilotic languages is the mid-vowel assimilation strategy. Uncharacteristically, in Ateso, roots consisting of mid-vowels assimilate to the vowels with similar peaks in the itive extensions. 


\section{References}

Barasa, D. 2015. Inflectional forms of tense and aspect in Ateso. The University of Nairobi Journal of Language and Linguistics 4: 82-102.

Barasa, D. 2017. Ateso Grammar: a descriptive account of an Eastern Nilotic Language. Muenchen: Lincom GmbH.

Casali, R.F. 2003. [ATR] value asymmetries and underlying vowel inventory structure in Niger-Congo and Nilo-Saharan. Linguistic Typology 7: 307-386.

Casali, R.F. 2008. ATR harmony in African languages. Language and Linguistics Compass 2/3: 496-549.

Dimmendaal, G.J. 1983. The Turkana language. Dordrecht: Foris Publications.

Dimmendaal, G.J. 2002. Constraining disharmony in Nilotic: What does an optimal system look like? Journal of African Languages and Linguistics 23: 41-69.

Dimmendaal, G.J. 2012. Metrical structures: A neglected property of Nilotic (and other African language families). Studies in Nilotic Linguistics 5: 1-26.

Gafos, A. \& Dye, A. 2011. Vowel harmony: Transparent and opaque vowels. In M. van Oosterdorp, C.J. Ewen, E. Hume, and K. Rice (eds.). The Blackwell companion to phonology. Malden, MA: Wiley-Blackwell. pp. 2164-2189

Otaala, L. 1981. Phonological and semantic aspects of Ateso derivational verbal morphology. Unpublished M.A. thesis, University of Nairobi.

Schroeder, M. \& Schroeder, H. 1987b. Vowel harmony in Toposa. Afrikanistische Arbeitspapiere. Schriftenreihe des Kölner Instituts für Afrikanistik 12:27-35.

Tucker, A.N. \& Bryan M.A. 1966. Linguistic analyses: The non-Bantu languages of Northeastern Africa. London: Oxford University Press for the International African Institute. 